\title{
The rare complication of Behcet's syndrome: concomitance of coronary slow flow with acute coronary syndrome
}

\author{
Huseyin Altug Cakmak, Emre Erturk, Baris Ikitimur, Bilgehan Karadag
}

Department of Cardiology, Cerrahpasa Medical Faculty, Istanbul University, Istanbul, Turkey

Correspondence to Dr Huseyin Altug Cakmak, altugcakmak@hotmail.com

\section{DESCRIPTION}

Coronary slow flow (CSF) is a phenomenon characterised by delayed opacification of coronary arteries in the absence of epicardial stenosis, in which microvascular and endothelial dysfunction have been implicated in pathophysiology. ${ }^{1}$ The association between acute coronary syndromes (ACS) and Behcet's syndrome is well known but rare, and is especially important due to the tendency to affect young subjects. Besides CSF, vasculitis, aneurysms, coronary vasospasm and thrombo-embolic phenomena may also lead to ACS in Behcet's syndrome. $^{2}{ }^{3}$ Vascular endothelial cell injury and resultant endothelial dysfunction seem to play a role in the CSF leading to ACS. ${ }^{12}$ We report a patient with Behcet's syndrome, and history of hypertension who had CSF presenting with severe myocardial ischemia leading to ACS. A 54-year-old woman was admitted with 2 hours of severe retrosternal chest pain and nausea. Physical

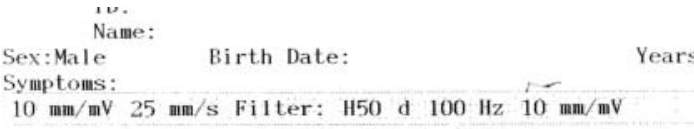

Name:
Sex:Male
Symptoms: Birth Date:
$10 \mathrm{~mm} / \mathrm{mV} 25 \mathrm{~mm} / \mathrm{s}$ Filter: $\mathrm{H} 50$ d $100 \mathrm{~Hz} \quad 10 \mathrm{~mm} / \mathrm{mV}$
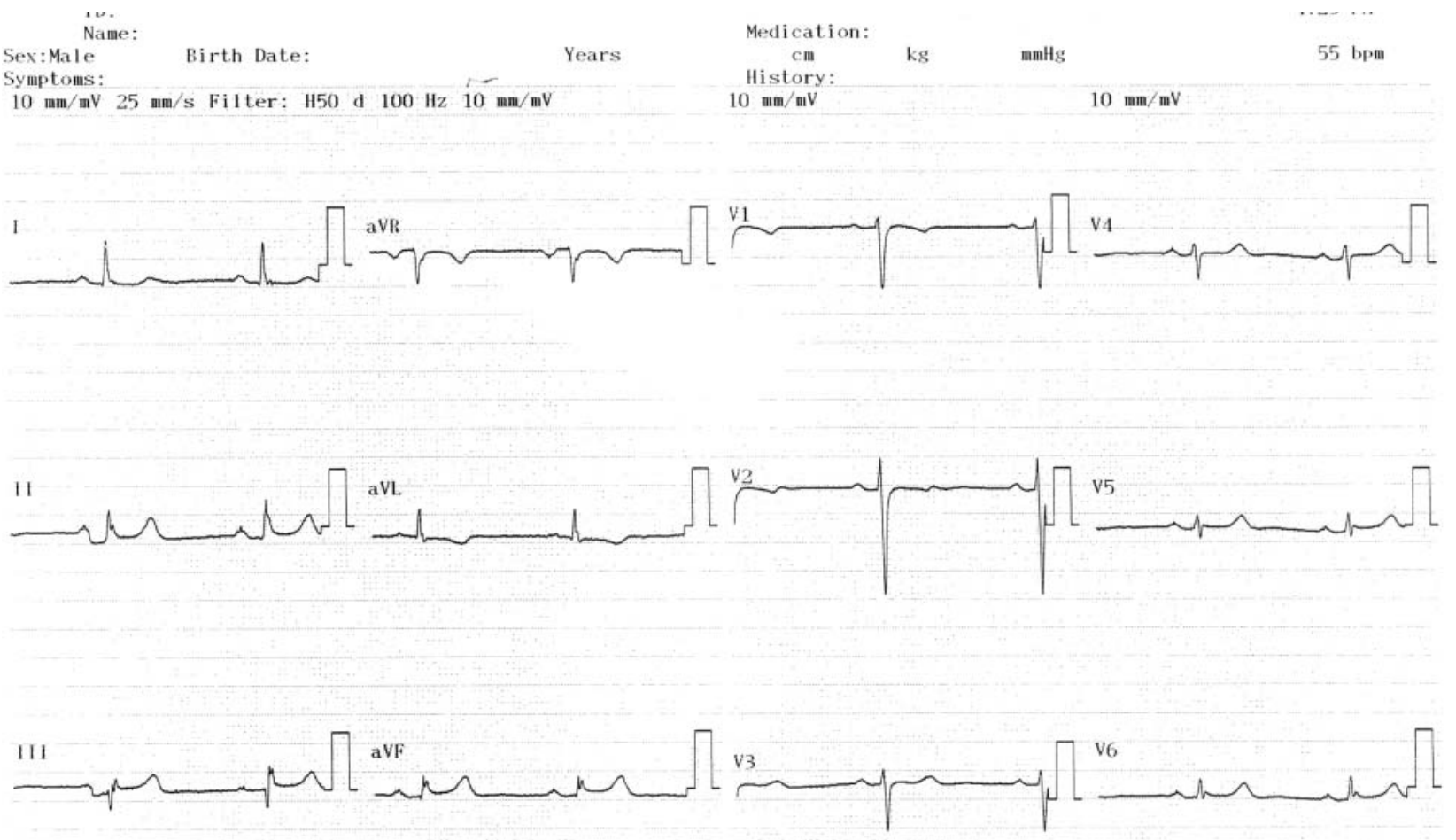

Rhytha[ II ] $10 \mathrm{~mm} / \mathrm{mV}$

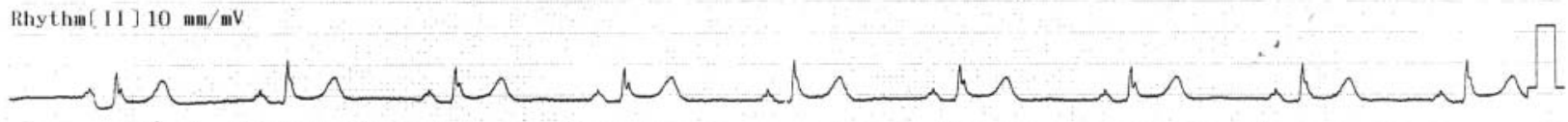

1350k 04-01 03-02 Dept.

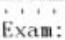

Figure 1 The ECG revealed sinus rhythm and $1 \mathrm{~mm}$ ST segment elevations in D-II-III-aVF derivations. 


\section{BMJ Case Reports}

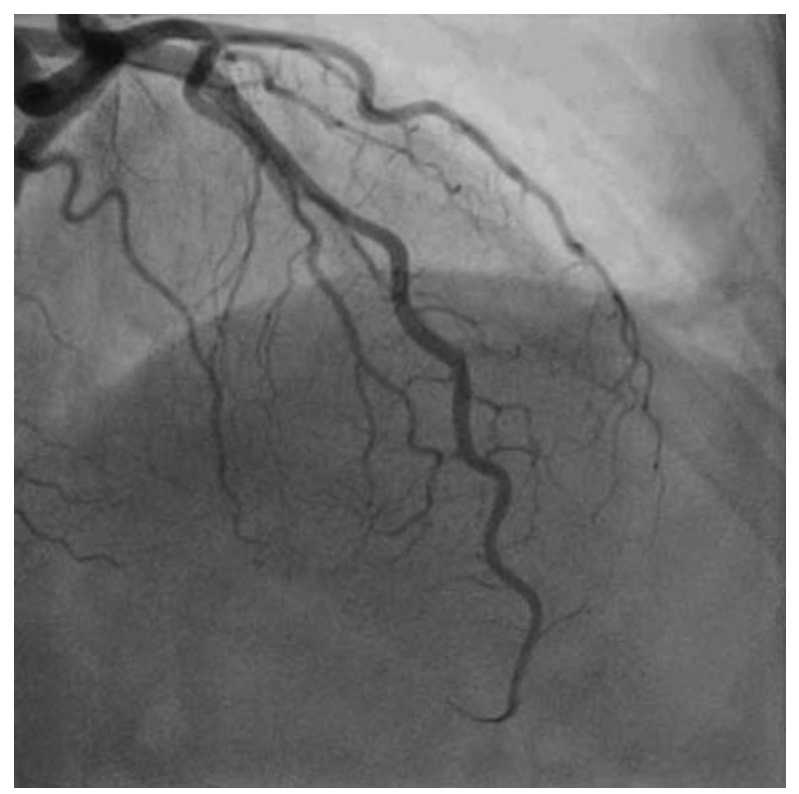

Videos 1 The coronary angiography revealed normal coronary arteries with marked slowing of coronary flow and delayed washout of contrast throughout lumen of left anterior descending and circumflex coronary arteries.

examination revealed a blood pressure of $125 / 80 \mathrm{~mm} \mathrm{Hg}$, a regular heart rate of 76 beats/min with normal auscultation findings. The electrocardiogram (ECG) revealed sinus rhythm and $1 \mathrm{~mm}$ ST segment elevations in D-II-III-aVF derivations (figure 1). The coronary angiography revealed normal coronary arteries with marked slowing down of coronary flow and delayed washout of contrast (videos 1-4). The echocardiogram at discharge



Videos 2 The coronary angiography revealed normal coronary arteries with marked slowing of coronary flow and delayed washout of contrast throughout lumen of left anterior descending and circumflex coronary arteries.

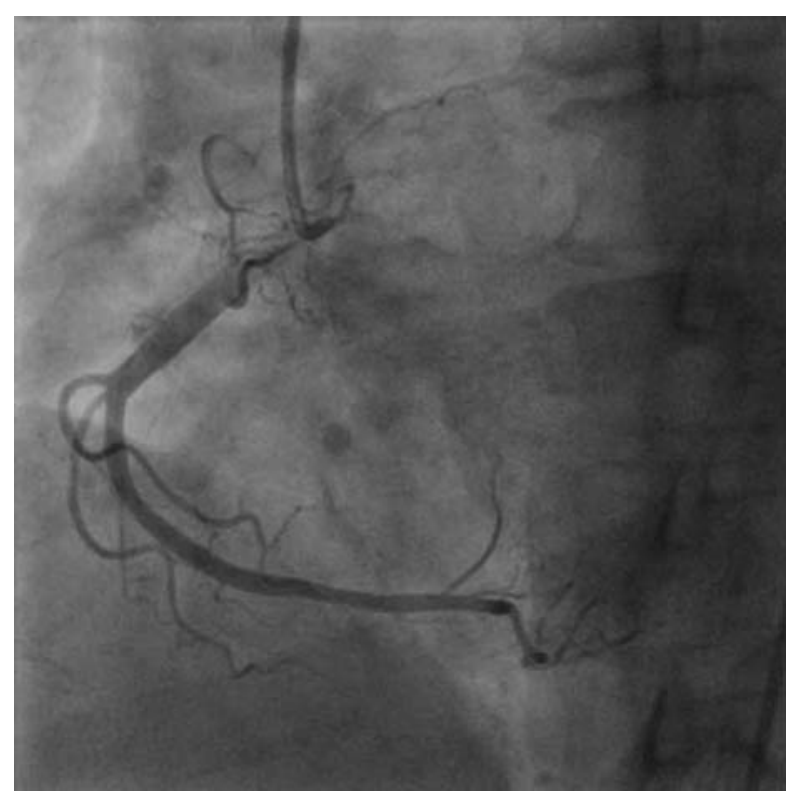

Videos 3 The coronary angiography revealed normal coronary arteries with marked slowing of coronary flow and delayed washout of contrast throughout lumen of right coronary artery.

showed no wall motion disturbances and an ejection fraction of $60 \%$. The initial and follow-up cardiac enzymes were found to be within the normal range. The patient was discharged after 3 days without any complications. No optimal therapeutic approach exists for CSF except for vasodilator agents as calcium-channel blockers and/or dipyridamole, which are beneficial for microvascular dysfunction. ${ }^{2} 3$

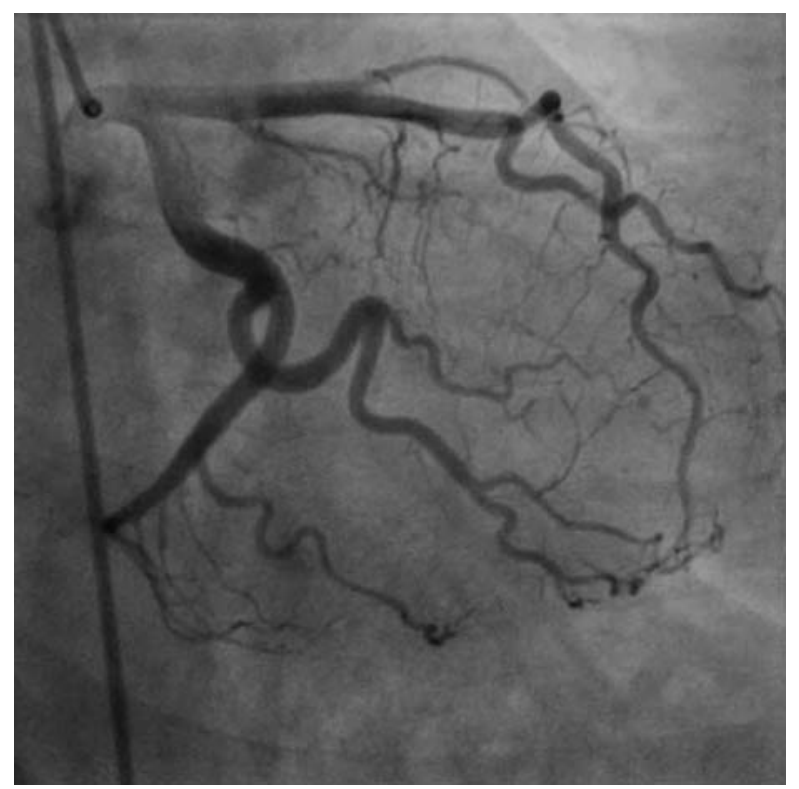

Videos 4 The coronary angiography showed normal coronary artery with marked slowing down of coronary flow and delayed washout of contrast throughout lumen of left anterior descending and circumflex coronary arteries. 


\section{BMJ Case Reports}

\section{Learning points}

- Coronary slow flow (CSF) is a phenomenon characterized by delayed opacification of coronary arteries in the absence of epicardial stenosis.

- Vascular endothelial cell injury and resultant endothelial dysfunction seem to play a role in the CSF leading to ACS.

- No optimal therapeutic approach exists for CSF except for vasodilator agents as calcium-channel blockers and/ or dipyridamole, which are beneficial for microvascular dysfunction.
Competing interests None

Patient consent Obtained.

\section{REFERENCES}

1. Kopetz V, Kennedy J, Heresztyn T, et al. Endothelial function, oxidative stress and inflammatory studies in chronic coronary slow flow phenomenon patients. Cardiology 2012;121:197-203.

2. Chambers JC, Haskard DO, Kooner JS. Vascular endothelial function and oxidative stress mechanisms in patients with Behçet syndrome. J Am Coll Cardiol 2001;37:517-20

3. Kosar F, Sahin I, Gullu H, et al. Acute myocardial infarction with normal coronary arteries in a young man with the Behçet disease. Int J Cardiol 2005;99:355-7.

This pdf has been created automatically from the final edited text and images.

Copyright 2012 BMJ Publishing Group. All rights reserved. For permission to reuse any of this content visit http://group.bmj.com/group/rights-licensing/permissions.

BMJ Case Report Fellows may re-use this article for personal use and teaching without any further permission.

Please cite this article as follows (you will need to access the article online to obtain the date of publication).

Cakmak HA, Erturk E, Ikitimur B, Karadag B. The rare complication of Behcet's syndrome: concomitance of coronary slow flow with acute coronary syndrome. BMJ Case Reports 2012;10.1136/bcr-2012-006388, Published XXX

Become a Fellow of BMJ Case Reports today and you can:

- Submit as many cases as you like

- Enjoy fast sympathetic peer review and rapid publication of accepted articles

- Access all the published articles

- Re-use any of the published material for personal use and teaching without further permission

For information on Institutional Fellowships contact consortiasales@bmjgroup.com

Visit casereports.bmj.com for more articles like this and to become a Fellow 